\title{
The China Factor in Hong Kong Elections
}

1991 to 2016

\section{Ma Ngok}

\section{OpenEdition}

\section{Journals}

Electronic version

URL: http://journals.openedition.org/chinaperspectives/7381

ISSN: 1996-4617

\section{Publisher}

Centre d'étude français sur la Chine contemporaine

\section{Printed version}

Date of publication: 1 September 2017

Number of pages: 17-26

ISSN: 2070-3449

\section{Electronic reference}

Ma Ngok, "The China Factor in Hong Kong Elections », China Perspectives [Online], 2017/3 | 2017,

Online since 01 September 2018, connection on 28 October 2019. URL : http://

journals.openedition.org/chinaperspectives/7381

This text was automatically generated on 28 October 2019 .

(c) All rights reserved 


\section{The China Factor in Hong Kong Elections}

1991 to 2016

\section{Ma Ngok}

\section{ABSTRACTS}

The China factor has always been a significant structural, ideological, and organisational factor in Hong Kong elections. Since 2003, the deepening of intervention by Beijing and its Liaison Office in Hong Kong meant that the China factor as an organisational force became increasingly salient in elections. It also drove more people, especially young people, to resist China's control and take the road of supporting independence or self-determination. The 2016 elections showed more ostensible intervention by the Liaison office, and independence became a new campaign issue. The China factor will continue to be an integral part of Hong Kong elections in years to come.

\section{INDEX}

Keywords: China factor, Hong Kong independence, Hong Kong politics, Umbrella Movement, Hong Kong identity, Legislative Council elections, Liaison Office 


\section{AUTHOR}

\section{MA NGOK}

Ma Ngok is Associate Professor at the Department of Government and Public Administration of the Chinese University of Hong Kong.Chinese University of Hong Kong, T.C. Cheng Building, United College, Shatin, New Territories, Hong Kong (mangok@cuhk.edu.hk). 